\title{
Retraction Note: Prediction microhardness profile of functionally graded steels by ANFIS
}

\author{
Hamid Bohlooli ${ }^{1}$ Ali Nazari ${ }^{2} \cdot$ Mohammad Mehdi Kaykha $^{3}$
}

Published online: 25 August 2020

(C) Springer-Verlag London Ltd., part of Springer Nature 2020

\section{Retraction Note: Neural Comput \& Applic (2013) 22:847-858 https://doi.org/10.1007/s00521-011-0775-3}

The Editor-in-Chief has retracted this article [1] because it significantly overlaps with a number of articles including those that were under consideration at the same time [2-4] and previously published articles [5,6]. Additionally, the article shows evidence of peer review manipulation and authorship manipulation. The authors have not responded to any correspondence regarding this retraction.

\section{References}

1. Bohlooli H, Nazari A, Kaykha MM (2013) Prediction microhardness profile of functionally graded steels by ANFIS. Neural Comput Appl 22:847-858. https://doi.org/10.1007/s00521-0110775-3
2. Nazari Ali, Azimzadegan Tohid (2012) Prediction the effects of $\mathrm{ZnO}_{2}$ nanoparticles on splitting tensile strength and water absorption of high strength concrete. Mater Res 15(3):440-454. https:// doi.org/10.1590/S1516-14392012005000057

3. Bohlooli H, Nazari A, Kaykha MM (2012) RETRACTED: analytical modeling of Charpy impact energy of functionally graded steels by ANFIS. Int J Damage Mech 21(6):913-939. https://doi.org/10.1177/1056789511431269

4. Nazari Ali (2012) Application of ANFIS for analytical modeling of tensile strength of functionally graded steels. Mater Res 3:383-396. https://doi.org/10.1590/S1516-14392012005000038

5. Nazari Ali, Khalaj Gholamreza, Riahi Shadi (2012) Application of ANFIS for analytical modeling of JIC of functionally graded steels. Math Comput Model 55(3-4):1339-1353. https://doi.org/ 10.1016/j.mcm.2011.10.013

6. Nazari A (2013) Application of artificial neural networks for analytical modeling of Charpy impact energy of functionally graded steels. Neural Comput Appl 22:731-745. https://doi.org/10. 1007/s00521-011-0761-9

Publisher's Note Springer Nature remains neutral with regard to jurisdictional claims in published maps and institutional affiliations.

The original article can be found online at https:// doi.org/10.1007/s00521-011-0775-3.

Ali Nazari

alinazari84@aut.ac.ir

1 Department of Mechanical Engineering, Birjand Branch, Islamic Azad University, Birjand, Iran

2 Department of Materials Science and Engineering, Saveh Branch, Islamic Azad University, Saveh, Iran

3 Young Researchers Club, Birjand Branch, Islamic Azad University, Birjand, Iran 